\title{
ANALISIS FAKTOR MOTIVASI TERHADAP EFEKTIVITAS ORGANISASI PADA KARYAWAN MEDICAL REPRESENTATIF AREA MALANG
}

\author{
Nurul Hidayatinnisa' \\ Jurusan Administrasi Niaga, Politeknik Negeri Malang \\ nurulnisa@polinema.ac.id
}

\section{Masreviastuti}

Jurusan Administrasi Niaga, Politeknik Negeri Malang masreviastuti@gmail.com

\section{Ayu Febriyanti Puspitasari \\ Jurusan Administrasi Niaga, Politeknik Negeri Malang ayufebriyanti@polinema.ac.id}

\begin{abstract}
Organizational effectiveness is an issue that is being considered by many organizations, organizational effectiveness can be a reference for whether the organization has succeeded in achieving its planned goals or objectives. Several factors affect the effectiveness of the organization, one of which is the motivational factors of the members of the organization. According to research from K.P. Singh (2017) the dominant motivational factors for organizational effectiveness are: recognition and empowerment. This study was conducted on medical representative employees who are the spearhead of pharmaceutical companies. It is known that medical representatives have a significant role in the company, so the company is expected to pay attention to the factors that affect employee motivation so that employee effectiveness is formed. This study includes a quantitative method of explanatory research using a questionnaire questionnaire to medical representative employees. The data analysis technique used is multiple linear regression analysis. The results of this study indicate that the motivational factors, namely recognition and empowerment, have a dominant influence on organizational effectiveness and partially or jointly have a significant effect on organizational effectiveness.
\end{abstract}

Keywords: organizational effectiveness, motivation factors : recognition and empowerment.

Corresponding author:

Email Address : nurulnisa@polinema.ac.id(Malang, Jawa Timur)

Received 15 Agustus 2021, Accepted 16 Agustus 2021, Published 22 Agustus 2021

\section{PENDAHULUAN}

Medical Representatif atau disingkat (MR) adalah tenaga ahli organisasi farmasi yang menjadi duta dalam mempromosikan atau mengenalkan produk - produk organisasi farmasi. Salah satu tugas dari MR adalah menjaga loyalitas tenaga kesehatan seperti dokter, perawat dan apoteker. Tanggung Jawab terhadap pemasaran obat - obatan menjadi tanggung jawab utama MR, maka posisi "Medical Representative" sangat penting kepada organisasi farmasi. Jadi dapat dikatakan bahwa MR adalah ujung tombak organisasi farmasi untuk kompetisi pasar industri farmasi di Indonesia.

Oganisasi harus memperhatikan faktor motivasi kepada medical representatif. Dalam menumbuhkan omzet penjualan obat, organisasi perlu memperhatikan terkait sumber daya manusia dan segala aspek kepada pekerjaannya. Menurut Notoatmodjo (1998) "Manusia sebagai salah satu komponen organisasi merupakan penentu tercapainya visi dan misi organisasi". Sumber daya manusia adalah pilar utama dalam menumbuhkan kapasitas organisasi dalam 
mengimplementasikan strategi bisnis dan mencapai tujuan dari organisasi.

Karyawan yang memimpin sebuah organisasi perlu bekerja lebih keras untuk melawan persaingan dan menjaga organisasi dan bisnis tetap hidup. Dalam situasi seperti itu, kehadiran seorang karyawan tidak mampu diabaikan dan harus ditanggapi dengan serius dengan menawarkan penghargaan dan penghargaan sebagai bentuk dorongan positif kekepada karyawan atau karyawan yang terlibat. Seperti yang dikemukakan Zainun (2001), munculnya motivasi kerja bagi karyawan sangat penting untuk mencapai tujuan pengelolaan sumber daya manusia. Ini menciptakan, mengembangkan, dan menyalakan kembali keinginan, persatuan, dan menyalakan kembali tingkat tinggi dalam kinerja tugas-tugas karyawan dan kelompok dalam suatu organisasi.

Herzberg (2008) menyebutkan ada faktor-faktor yang memotivasi karyawan untuk memperoleh kepuasan dalam bekerja atau melakukan aktivitas. Faktor tersebut disebut sebagai Motivator. Faktor tersebut meliputi Prestasi, Recognition, Pekerjaan itu Sendiri, tanggung Jawab dan empowerment. Dalam penelitian Mazoor (2012) menyebutkan bahwa ada dua faktor yang dominan terhadap motivasi yaitu recognition dan empowerment.

Recognition artinya karyawan memperoleh recognitionatau pengakuan dari pihak organisasi ataupun atasan bahwa ia adalah orang berprestasi, sehingga patut diberi penghargaan, di-manusia-kan, pujian. Motivasi diartikan sebagai proses kesediaan melakukan suatu usaha untuk mencapai sasaran yang ditetapkan organisasi, (Robbins, 2001). Dengan diberikan recognition oleh organisasi maka karyawan akan merasa diakui dan dihargai oleh organisasi. Tentu akan menimbulkan rasa senang lalu kepuasan atas recognition yang diberikan oleh organisasi.

Berdasarkan teori dua faktor Herzberg dimampu hasil bahwa faktor recognition termasuk kedalam faktor motivasional yang mampu memotivasi karyawan dalam bekerja. Selain itu, termampu penelitian yang dilakukan oleh Manoor (2020) yang menghasilkan kesimpulan bahwa recognition berpengaruh terhadap motivasi kerja. Di samping recognition, faktor lain motivasi adalah empowerment. Empowerment merupakan sebuah proses motivasi dari pengalaman karyawanyang merasa diberdayakan. Pakar manajemen, sepakat menyatakan bahwa empowerment akan mendatangkan manfaat dan keuntungan bagi organisasi (Anderson dan Adams, 1997 yang dikutip oleh lutans 2006).

Empowerment dipandang mampu menumbuhkan kreativitas para karyawan. Sedangkan kreatifitas sendiri merupakan landasan bagi tumbuh berkembangnya sebuah inovasi. Efektivitas organisasi sendiri didefinisikan sebagai sejauh mana sebuah organisasi, dengan menggunakan sumber daya tertentu, tetap mampu memenuhi tujuannya tanpa menghabiskan sumber daya dan tanpa menempatkan ketegangan yang tidak semestinya kepada anggota atau masyarakat. Selanjutnya untuk menjawab pertanyaan bagaimana hubungan antara faktor motivasi dengan efektivitas organisasi, Steers (1997) mengemukakan bahwa "motivasi perseorangan dalam suatu organisasi berdampak langsung kepada arah pencapaian tujuan organisasi.

Sebagaimana kepada penjelasan teori motivasi kepada level organisasi tersebut di atas, mampu diambil kesimpulan bahwa prestasi kerja atau kinerja karyawanal yang didorong oleh motivasi, secara otomatis akan mempengaruhi kinerja organisasi dalam upaya mencapai tujuan yang telah ditetapkan". Tujuan penelitian yang ingin dicapai peneliti dalam penelitian ini adalah untuk mengetahui pengaruh signifikan faktor motivasi recognition berpengaruh signifikan terhadap efektivitas organisasi. Dalam mengetahui pengaruh signifikan faktor motivasi empowerment berpengaruh signifikan terhadap efektivitas organisasi, dan terakhir untuk mengetahui pengaruh signifikan faktor motivasi yang terdiri dari recognition dan empowerment secara bersama - sama berpengaruh signifikan terhadap efektivitas organisasi.

Dalam meminimalisasi kemungkinan terjadinya kesalahan dalam penafsiran judul, maka masalah - masalah dalam penelitian ini dibatasi pada sejauh mana pengaruh langsung faktor - faktor motivasi, yaitu recognition dan empowerment kepada efektifitas organisasi. Penelitian ini dibatasi kepada reponden yang termasuk di dalamnya adalah karyawan bagian medical representative 
kepada kantor distributor PT. APL di area Malang. Manfaat yang diharapkan dari penelitian ini untuk menambah pengetahuan tentang bagaimana hubungan recognition dan empowerment tugas - tugas karyawan terhadap efektivitas organisasi. Bagi organisasi harapkan mampu memberikan masukan kepada organisasi dalam menentukan dan melaksanakan kebijakan organisasi terutama dalam hal empowerment tugas - tugas karyawan, recognition kerja karyawan, memotivasi karyawan, dan menumbuhkan efektivitas organisasi, dan bagi penelitian selanjutnya mampu digunakan sebagai referensi, tambahan informasi, dan bahan masukan atau pertimbangan untuk melakukan penelitian lebih lanjut. Kerangka konseptual penelitian adalah pada Gambar 1. berikut:

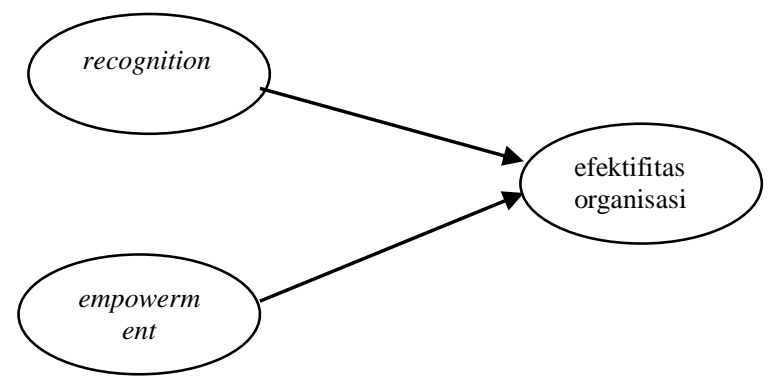

\section{Gambar 1. Kerangka Konseptual Penelitian}

\section{METODOLOGI PENELITIAN}

Pendekatan penelitian yang digunakan dalam penelitian ini adalah "Explanatory research atau confirmatory". Sebagaimana yang dinyatakan Singaribun (1995) bahwa explanatory research digunakan untuk menjelaskan hubungan kausal antara variabel -variabel, melalui pengujian hipotesis, di mana dalam penelitian ini explanatory research digunakan untuk menguji hipotesis tentang ada tidaknya pengaruh dari faktor motivasi yang terdiri dari recognition dan empowerment terhadap efektivitas organiasi medical representative, sehingga variabel yang digunakan adalah variabel motivasi $(\mathrm{X})$ sebagai variabel bebas yang terdiri dari Recognition (X1), Empowerment (X2), serta Efektivitas Organisasi (Y) sebagai variabel terikat. Dalam pelaksanaannya menggunakan metode survei.
Agar konsep mampu diteliti secara empiris harus dioperasionalkan dengan mengubahnya menjadi variabel, yang berarti sesuatu yang mempunyai variasi nilai. Adapun variabel - variabel yang digunakan dalam penelitian ini adalah sebagaia berikut:

1. Variabel Recognition

Adalah perlakuan yang mendorong karyawan bersedia dan mau bekerja dengan giat dan semangat untuk memenuhi kebutuhan dan keinginanya. Indikator yang digunakan adalah (Andriani, M. \& Widiawati, K., 2017) kesadaran upaya karyawan, hadiah upaya pemecahan masalah, hadiah pertemuan sukses, sistem laba, hadiah kinerja.

2. Variabel Pemberdayaan Kerja

Berperan membantu mengoptimalkan kinerja karyawan dan melakukan pekerjaan terukur dengan baik. Ciptakan situasi yang memotivasi organisasi, kemampuan karyawan untuk melakukan semua pekerjaan yang mungkin dalam bentuk berbagi pengetahuan, keterampilan serta kepercayaan diri. Variabel efisiensi suatu organisasi adalah kemampuan atau keberhasilan organisasi dalam melaksanakan tugas dan fungsinya untuk mencapai tujuan yang telah ditetapkan. Diukur dengan ukuran kinerja pegawai, produktivitas pegawai, kepuasan kerja pegawai, dan komitmen pegawai untuk meningkatkan kinerja.

Pengumpulan data yang digunakan dalam survei ini adalah survei skala Likert yang menggunakan durasi tanggapan untuk setiap responden dengan skor 15. Skala Likert digunakan untuk memantau koordinasi sikap, keterampilan dan persepsi karyawan atau karyawan, kelompok orang (yang diwawancarai). Pada fenomena sosial yang akan dipelajari. mengguunakan skala Likert interval yang mewakili nilai skala yang sama dengan karakteristik yang akan diukur (Widayat, 200). Skala ini memiliki satuan ukuran yang sama untuk mengetahui jarak dari satu titik ke titik lainnya. Skor diberi bobot pada skala jarak sebagai berikut: Skor sangat setuju (SS), Jawaban dengan skor setuju (S), Jawaban dengan skor 3 netral (N), Jawaban tidak Respon Sangat Tidak Setuju 
(STS ) dengan persetujuan (TS) skor 2 dan nilai 1.

\section{Jenis Data dan Sumber}

Jenis data yang digunakan dalam penelitian ini adalah data kualitatif dan kuantitatif. Data primer kepada penelitian ini diperoleh melalui penyebaran kuesioner kepada responden, dalam hal ini karyawan medical representative area Malang. Data sekunder dalam penelitian ini berasal dari jurnal, literatur, laporan penelitian yang mendukung penelitian ini.

\section{Prosedur Pengumpulan Data, Populasi dan Sampel}

Prosedur pengumpulan data menggunakan kuesioner yang dibuat berdasarkan indikatorindikator dari variabel yang dijawab oleh responden, kemudian wawancara adalah teknik pengumpulan data dengan mengajukan pertanyaan dari pewawancara kepada responden, dan jawaban dari responden dicatat atau direkam. Observasi adalah metode pengumpulan data yang paling umum dilakukan oleh peneliti, utamanya yang meneliti tentang perilaku manusia.

\section{Populasi dan Sampel}

Penentuan populasi dan sampel dalam penelitian adalah penting, hal ini untuk mengetahui siapa yang menjadi populasi serta besarnya sampel yang diambil dari populasi, sehingga didapat perkiraan secara tepat tentang jumlah sampel yang akan mewakili. Populasi kepada penelitian ini adalah karyawan medical representative Malang yang berkantor di kantor distribusi PT. APL yang jumlahnya 37 orang. Suharsimi Arikunto (1993;177) menyatakan bahwa "Bila populasi kurang dari 100 lebih baik diambil semua sebagai sampel penelitian, sehingga penelitian ini merupakan penelitian populasi".Oleh karena, jumlah populasi karyawan medical representative Malang yang berkantor $\mathrm{di}$ kantor distribusi PT. APL hanya 37 karyawan maka jumlah tersebut akan dijadikan sebagai subjek penelitian dan sehingga penelitian ini adalah penelitian populasi atau disebut sensus.

\section{Teknik Analisis}

\section{Koefisien R-square}

Koefisien $\mathrm{R}$ square $\left(\mathrm{R}^{2}\right)$ digunakan untuk mengetahui besarnya sumbangan pada keseluruhan variabel $(\mathrm{X} 1, \mathrm{X} 2)$ dan pengaruhnya terhadap variabel terikat $(\mathrm{Y})$, sedangkan sisanya dipengaruhi oleh variabel yang tidak dimasukkan ke dalam model (Budi, 2007).

\section{Uji Hipotesis}

Dalam penelitian ini analisis regresi berganda digunakan untuk mengetahui pengaruh faktor motivasi yang tercermin dalam dua variabel yaitu : recognition dan Empowerment terhadap efektivitas organisasi.

\section{Uji F}

Adapun kriteria keputusan adalah apabila Fhitung > F Tabel $(\alpha, n-1)$ maka dikatakan secara bersama-sama variable independen atau bebas berpengaruh signifikan terhadap variable terikat, demikian sebaliknya.

Hipotesis dalam pengujian ini adalah sebagai berikut :

$\mathrm{H} 0$ : tidak ada pengaruh yang signifikan secara simultan variabel bebas $\mathrm{X}$ dengan variable terikat $\mathrm{Y}$.

Ha: ada pengaruh yang signifikan secara simultan antara variable bebas $\mathrm{X}$ dengan variable terikat $\mathrm{Y}$.

\section{Uji T}

Dalam mengetahui pengaruh variabel bebas secara parsial terhadap variabel terikat, digunakan uji $T$. Dalam penelitian ini nilai alpha $(\alpha)$ yang digunakan adalah sebesar 0,05 . Jika nilai probabilitas lebih kecil dari nilai alpha $(\alpha)$, maka variabel independen (X) yang diuji secara nyata berpengaruh terhadap variabel dependen (Y).Dalam Riduwan (2007: 96) untuk mengetahui signifikan regresi ganda mampu diketahui dengan membandingkan antara nilai probabilitas 0,05 dengan nilai probalitas sebagai berikut:

Jika nilai probalitas 0,05 lebih kecil atau sama dengan nilai probabilitas Sig atau $(0,05 \leq \mathrm{Sig})$ maka $\mathrm{HO}$ diterima dan Ha ditolak artinya tidak signifikan. Jika nilai probalitas 0,05 lebih besar atau sama dengan nilai probalitas Sig atau $(0,05 \geq \mathrm{Sig})$ maka $\mathrm{H} 0$ ditolak dan $\mathrm{Ha}$ diterima artinya signifikan.

\section{Uji Asumsi Klasik}

Salah satu syarat untuk bias menggunakan persamaan regresi berganda adalah terpenuhinya asumsi klasik. Agar nilai pemeriksa yang tidak bias dan efisien (Best 
Linier Unbias Estimator/ BLUE), perlu dilakukan pengujian untuk mengetahui model regresi yang dihasilkan memenuhi persyratan asumsi klasik. Agar mampu nilai yang tidak bias dan efisien dari persamaan regresi, maka dalam pelaksanaan analisis data harus memenuhi beberapa kriteria asumsi klasik sebagai berikut:

\section{Uji Non Multikolineritas}

Menurut Ghozali (2005) uji asumsi klasik multikolinearitas bertujuan untuk menguji apaka model regresi ditemukan adanya korelasi antara variabel bebas (independent). Model regresi yang baik seharusnya tidak terjadi korelasi diantara variabel independen. Jika terjadi korelasi maka dinamakan termampu masalah multikolinearitas. Hasan dalam Budi (2007) non multikolinearitas adalah hubungann anatara variabel bebas yang satu dengan variabel bebas yang lainya dalam model regresi tidak terjadi hubungan yang mendekati sempurna ataupun hubungan yang sempurna. Hubungan antara dua variabel bebas yang tidak mengandung multikolinearitas adalah apabila nilai $\mathrm{r}$ kurang dari 0,6 .

\section{Uji Non Heteroskedastisitas}

Menurut Ghozali (2005) tujuan dari uji asumsi klasik regresi berganda ini adalah untuk menguji apakah dalam sebuah model regresi termampu ketidaksamaan varian dan residual satu pengamatan ke pengamatan lainya tetap maka disebut homoskedastisitas dan jika berbeda disebut heteroskedastisitas. Mendeteksi heteroskedastisitas mampu dilihat dari scatterplot dengan melihat ada tidaknya pola tertentu kepada grafik, di mana sumbu $X$ adalah $\mathrm{Y}$ yang dipresiksi, dan sumbu $\mathrm{Y}$ adalah residual $(\mathrm{Y}$ prediksi $=\mathrm{Y}$ sesungguhnya). Jika ada pola tertentu seperti titik-titik yang menyebar membentuk pola teratur (bergelombang, melebar kemudian menyempit) maka terjadi heteroskedastisitas. Jika tidak ada pola yang jelas serta titik-titik menyebar secara acak di atas dan dibawah angka 0 kepada sumbu Y, maka tidak termasuk heteroskedastisitas.

\section{Uji Nomalitas}

Ghozali (2005), uji normalitas bertujuan untuk menguji apakah dalam model regresi, variabel pengganggu atau residual memiliki distribusi normal. Salah satu cara yang mampu digunakan untuk melakukan uji normalitas adalah dengan menggunakan analisis grafik. Distribusi normal akan membentuk satu garis lurus diagonal dan ploting data residual akan dibandingkan dengan garis diagonal.

\section{Validitas dan Reliabilitas Alat Ukur Uji Validitas}

Validitas adalah suatu ukuran yang menunjukan tingkat-tingkat kevalidan atau kesahian suatu instrumen (Arikunto, 2002:144). Valid tidaknaya suatu item instrumen mampu diketahui dengan membandingkan indeks korelasi product moment Pearson dengan level Signifikan 5\% dengan nilai kritisnya. Bila probabilitas hasil korelasi lebih kecil ( <) dari 0,05 (5\%), maka dinyatakan valid dan jika sebaliknya probabiltas hasil korelasi lebih besar (>) dari $0,05 \%(5 \%)$ maka dinyatakan tidak valid. Pengujian validitas dalam penelitian ini menggunakan bantuan komputer melalui program SPSS versi 26 for windows dengan menggunakan alternatif kedua dari penmampu Budi (2007).

\section{Uji Reliabilitas}

Reliabilitas adalah indeks yang menunjukan sejauh mana suatu alat pengukur mampu dipercaya atau mampu diandalkan (Singarimbun, 1995). Nilai koefisien reliabilitas berkisar antara nol sampai satu. Apabila nilai koefisien mendekati satu, maka instrumen tersebut semakain reliabel. Ukuran yang digunakan untuk menunjukan pernytaan tersebut reliabel, apabila nilai Chronbach Alpha di atas 0,6 (Arikunto, 2002). Pada penelitian ini, dalam menguji reliabilitas peneliti menggunakan bantuan komputer software SPSS versi 26.0 for windows dengan sumber data dari jawaban responden kepada kuesioner.

\section{HASIL \\ Karakteristik Responden \\ Responden Berdasarkan Jenis Kelamin}

Distribusi jenis kelamin pada responden karyawan medical representative. Tabel 1 . di bawah menunjukkan bahwa sebagian besar karyawan bagian karyawan medical representative. Tabel 1 . berjenis kelamin laki - laki sebanyak 25 responden $(65,57 \%)$ dan berjenis kelamin perempuan sebanyak 12 responden $(32,43 \%)$, ini menunjukkan 
department karyawan medical representative lebih banyak karyawan laki-laki.

Tabel 1. Jenis Kelamin Responden

\begin{tabular}{|c|c|c|c|}
\hline No. & Jenis Kelamin & Frekuensi & Persen \\
\hline 1. & Laki- laki & 25 & $65,57 \%$ \\
\hline 2. & Perempuan & 12 & $32,43 \%$ \\
\hline & Total & 37 & $100 \%$ \\
\hline
\end{tabular}

Sumber: data diolah, 2020

\section{Responden Berdasarkan Kelompok Usia}

Distribusi usia responden karyawan medical representativemampu dilihat berikut ini:

Tabel 2. Kelompok Usia Responden

\begin{tabular}{|l|c|c|c|}
\hline No. & Usia & Frekuensi & Persen \\
\hline 1. & Kurang dari 25 tahun & 15 & $40,54 \%$ \\
\hline 2. & Antara $26-30$ tahun & 9 & $24,32 \%$ \\
\hline 3. & Antara $31-35$ tahun & 7 & $18,92 \%$ \\
\hline 4. & Antara $36-40$ tahun & 6 & $16,22 \%$ \\
\hline & Total & 37 & $100 \%$ \\
\hline
\end{tabular}

Sumber: data diolah, 2021

Berdasarkan Tabel 2. di atas menunjukkan bahwa responden bagian karyawan medical representative yang berumur kurang dari 25 tahun sebanyak 15 responden $(40,54 \%)$, berumur 26-30 tahun sebanyak 9 responden (24.32\%), berumur antara 31-36 tahun sebanyak 7 responden $(18,92 \%)$ dan yang berumur 36-40 tahun sebanyak 6 responden $(16,22 \%)$, ini menunjukkan bahwa sebagian besar karyawan bagian karyawan medical representative lebih didominasi oleh pemudah berusia kurang dari 25 tahun.

\section{Responden Berdasarkan Status}

Distribusi status responden karyawan responden karyawan medical representative:

Tabel 3. Status Responden

\begin{tabular}{|c|c|c|c|}
\hline No. & Status & Frekuensi & Persen \\
\hline 1. & Belum Menikah & 11 & $29,73 \%$ \\
\hline 2. & Menikah & 26 & $70,27 \%$ \\
\hline & Total & 37 & $100 \%$ \\
\hline
\end{tabular}

Sumber: data diolah, 2020

Berdasarkan Tabel 3. dapat diketahui bahwa 37 responden dimampukan 11 responden $(29,73 \%)$ belum menikah dan 26 responden $(70,37)$ sudah menikah, menunjukkan bahwa sebagian besar karyawan bagian karyawan medical representative sudah berkeluarga.

\section{Responden Berdasarkan Masa Kerja}

Berdasarkan tabel di atas menunjukkan bahwa responden bagian karyawan medical representative yang masa kerja kurang 3 tahun sebanyak 15 responden $(40,54 \%)$, masa kerja 3-5 tahun sebanyak 9 responden (24.32\%), masa kerja 5-7 tahun sebanyak 7 responden $(18,92 \%)$ dan masa kerja 7-9 tahun sebanyak 6 responden $(16,22 \%)$, ini menunjukkan bahwa sebagian besar karyawan bagian karyawan medical representative loyak terhadap suatu organiasi.

Tabel 4. Masa Kerja Responden

\begin{tabular}{|c|c|c|c|}
\hline No. & Masa Kerja & Frekuensi & Persen \\
\hline 1. & Kurang dari 3 tahun & 15 & $40,54 \%$ \\
\hline 2. & Antara 3 - 5 tahun & 9 & $24,32 \%$ \\
\hline 3. & Antara 5 - 7 tahun & 7 & $18,92 \%$ \\
\hline 4. & Antara 7 $\underline{\underline{\underline{9}} \text { tahun }}$ & 6 & $16,22 \%$ \\
\hline & Total & 37 & $100 \%$ \\
\hline
\end{tabular}

Sumber: data diolah, 2020

\section{Deskripsi Variabel Penelitian}

Hasil penelitian ini diperoleh dari hasil penyebaran koesioner dengan jumlah responden sebanyak 37 orang. Koesioner terdiri dari 2 variabel bebas dimana terdiri yaitu: recognition dan empowerment. Sedangkan yang menjadi variabel terikatnya adalah efektivitas organiasi Dalam panyajian kuesioner indikator kepada setiap variabel bebas recognition dengan lima pertanyaan, empowerment dengan empat pertanyaan dan untuk efektivitas organiasi dengan empat pertanyaan. Deskripsi jawaban responden merupakan hasil jawaban responden kepada masing - masing variabel penelitian. Deskripsi jawaban akan dijelaskan berdasarkan frekuensi dan hasil perhitungan mean masingmasing variabel yang sudah dikategorikan. Adapun jawaban mampu di jelaska kepada tabel berikut ini :

\section{Deskripsi Variabel Recognition}

Variabel recognition memiliki 5 indikator. Deskripsi mengenai indikator tersebut dijelaskan kepada halaman berikutnya. Tabel 5. di atas menunjukkan bahwa tanggapan sebagian besar responden terhadap recognition adalah "cukup setuju" karena dari semua pernyataan memiliki nilai rata-rata 3.51. Lima pernyataan mengenai recognition, semuanya memiliki rata-rata diatas 3 dengan rata - rata terendah sebesar 3.18 kepada 
pernyataan "Anda mampu penghargaan/poin terhadap upaya pemecahan masalah (problem solving) terkait dengan complain dari tamu ataupun pelanggan" dan rata-rata tertinggi sebesar 4,21 kepada pernyataan "Anda mampu gaji sesuai target organisasi”.

Berikut tanggapan responden dari seluruh indikator variabel recognition.

Tabel 5. Variabel Recognition

\begin{tabular}{|c|c|c|c|c|c|c|c|c|}
\hline \multirow[b]{2}{*}{ No. } & \multirow[b]{2}{*}{ Pertanyaan } & \multicolumn{5}{|c|}{ Skor } & \multirow[b]{2}{*}{ Total } & \multirow[b]{2}{*}{ Mean } \\
\hline & & 1 & 2 & 3 & 4 & 5 & & \\
\hline 1 & $\mathrm{X} 1.1$ & - & 7 & 12 & 13 & 5 & 37 & 3,34 \\
\hline 2 & $\mathrm{X} 1.2$ & - & 8 & 14 & 15 & - & 37 & 3,18 \\
\hline 3 & $\mathrm{X} 1.3$ & - & 3 & 10 & 22 & 2 & 37 & 3,62 \\
\hline 4 & $\mathrm{X} 1.4$ & - & 2 & 7 & 9 & 19 & 37 & 4,21 \\
\hline 5 & $\mathrm{X} 1.5$ & 3 & 7 & 11 & 15 & 1 & 37 & 3,10 \\
\hline & & Mea & $\mathrm{To}$ & & & & & 3,51 \\
\hline
\end{tabular}

Sumber: data diolah, 2020

\section{Deskripsi Variabel Empowerment}

Variabel empowerment memiliki 4 indikator. Deskripsi mengenai indikator tersebut dijelaskan kepada halaman berikutnya. Berikut tanggapan responden dari seluruh indikator variabel empowerment

Tabel 6. Variabel Empowerment

\begin{tabular}{|c|c|c|c|c|c|c|c|c|}
\hline \multirow[b]{2}{*}{ No. } & \multirow[b]{2}{*}{ Pertanyaan } & \multicolumn{5}{|c|}{ Skor } & \multirow[b]{2}{*}{ Total } & \multirow[b]{2}{*}{ Mean } \\
\hline & & 1 & 2 & 3 & 4 & 5 & & \\
\hline 1 & $\mathrm{X} 2.1$ & & 4 & 11 & 21 & 1 & 37 & 3.51 \\
\hline 2 & $\mathrm{X} 2.2$ & - & - & 10 & 16 & 11 & 37 & 4.02 \\
\hline 3 & $\mathrm{X} 2.3$ & - & - & 7 & 14 & 16 & 37 & 4.24 \\
\hline 4 & $\mathrm{X} 2.4$ & - & 5 & 17 & 13 & 2 & 37 & 3.32 \\
\hline \multicolumn{8}{|c|}{ Mean Total } & 3.77 \\
\hline
\end{tabular}

Sumber: data diolah, 2020

Tabel 6. menunjukkan bahwa tanggapan sebagian besar responden terhadap empowerment adalah "setuju" karena dari semua pernyataan memiliki nilai rata - rata 3.77. Empat pernyataan mengenai empowerment, semuanya memiliki rata-rata diatas 3 dengan rata-rata terendah sebesar 3.32 kepada pernyataan "Anda memperoleh kebebasan dalam melakukan semua pekerjaan serta berbagi pengetahuan, keterampilan dan mempunyai rasa percaya diri yang tinggi" dan rata - rata tertinggi sebesar 4,24 kepada pernyataan "Anda mampu mengikuti aturan baik secara internal (antar karyawan), secara horizontal (dengan tamu, pelanggan, dan fungsi- fungsi lainnya), serta secara vertikal (dengan organisasi induk)".
Deskripsi variabel Efektivitas organiasi (Y) Variabel efektivitas organiasi memiliki 4 indikator. Deskripsi mengenai indikator tersebut dijelaskan kepada halaman berikutnya. Berikut tanggapan responden dari seluruh indikator variabel efektivitas organiasi.

Tabel 7. Variabel Efektivitas Organiasi (Y)

\begin{tabular}{|c|c|c|c|c|c|c|c|c|}
\hline \multirow[b]{2}{*}{ No. } & \multirow[b]{2}{*}{ Pertanyaan } & \multicolumn{5}{|c|}{ Skor } & \multirow[b]{2}{*}{ Total } & \multirow[b]{2}{*}{ Mean } \\
\hline & & 1 & 2 & 3 & 4 & 5 & & \\
\hline 1 & $\mathrm{X} 2.1$ & & 4 & 11 & 21 & 1 & 37 & 3.51 \\
\hline 2 & $\mathrm{X} 2.2$ & - & - & 10 & 16 & 11 & 37 & 4.02 \\
\hline 3 & $\mathrm{X} 2.3$ & - & - & 7 & 14 & 16 & 37 & 4.24 \\
\hline 4 & $\mathrm{X} 2.4$ & - & 5 & 17 & 13 & 2 & 37 & 3.32 \\
\hline \multicolumn{8}{|c|}{ Mean Total } & 3.77 \\
\hline
\end{tabular}

Sumber: data diolah, 2020

Tabel 7. menunjukkan bahwa tanggapan sebagian besar responden terhadap efektivitas organiasi adalah "setuju" karena dari semua pernyataan memiliki nilai rata-rata 3.73. Empat pernyataan mengenai efektivitas organisasi, semuanya memiliki rata-rata diatas 3 dengan rata - rata terendah sebesar 3.51 kepada pernyataan "Anda selalu menmampu nilai baik ketika dilakukan Penilaian Prestasi Kerja atau Performance Appraisal (PA)." dan rata-rata tertinggi sebesar 3,89 kepada pernyataan "Anda merasa yakin dengan visi, misi dan tujuan organisasi serta mempunyai loyalitas yang tinggi terhadap organisasi.".

\section{Pengujian Instrumen}

Agar data yang diperoleh mempunyai arti dan mampu diinterpretasikan, maka perlu dilakukan analisis terhadap data tersebut. Dalam analisis data ini dilakukan pengujian hipotesa atas semua variabel yang diteliti, hal ini dimaksudkan untuk membuktikan adanya pengaruh antara variabel bebas dan variabel terikat secara keseluruhan sebagaimana dinyatakan dalam hipotesis yang dikemukakan kepada bab terdahulu. Adapun beberapa uji statistik yang dilakukan adalah sebagai berikut :

\section{Uji Validitas}

Uji validitas dilakukan untuk melihat valid tidaknya masing-masing instrumen dalam variabel Recognition $\mathrm{X} 1, \quad$ variabel Empowerment $\mathrm{X} 2$, dan variabel Efektifitas organiasi Y. Nilai kritis dari pengujian ini adalah kepada df $=\mathrm{n}-1$ dengan taraf signifikansi $5 \%$. Butir instrumen dikatakan valid jika angka korelasi yang diperoleh di atas angka kritis korelasi atau nilai 
probabilitasnya kurang dari 0,05 . (Burhan Nurgiyantoro, 2000) Adapun uji hasil validitas kepada pengujian ini adalah :

Tabel 8. Uji Validitas X.1

\begin{tabular}{|c|c|c|c|c|}
\hline Item & $\begin{array}{c}\text { Validitas } \\
\text { ( } \mathrm{r} \text { hitung) }\end{array}$ & $\mathrm{r}$ table & Prob. & Keterangan \\
\hline $\mathrm{X} 1.1$ & 0,700 & 0,2126 & 0,000 & Valid \\
$\mathrm{X} 1.2$ & 0,503 & 0,2126 & 0,000 & Valid \\
$\mathrm{X} 1.3$ & 0,730 & 0,2126 & 0,000 & Valid \\
$\mathrm{X} 1.4$ & 0,848 & 0,2126 & 0,000 & Valid \\
$\mathrm{X} 1.5$ & 0,655 & 0,2126 & 0,000 & Valid \\
\hline
\end{tabular}

Sumber : data diolah, 2020

Tabel 8. dapat disimpulkan bahwa semua instrumen dalam variabel Recognition (X1) adalah valid, hal ini dibuktikan dengan nilai masing - masing koefisien korelasi dari masing-masing item $r$ hitung $>r$ tabel atau probablitas kurang dari 0,05 , sehingga mampu digunakan dalam pengujian selanjutnya.

Tabel 9. Uji Validitas X.1

\begin{tabular}{|c|c|c|c|c|}
\hline Item & $\begin{array}{c}\text { Validitas } \\
\text { (r hitung) }\end{array}$ & $\mathrm{r}_{\text {table }}$ & Prob. & Keterangan \\
\hline $\mathrm{X} 2.1$ & 0,736 & 0,2126 & 0,000 & Valid \\
$\mathrm{X} 2.2$ & 0,767 & 0,2126 & 0,000 & Valid \\
$\mathrm{X} 2.3$ & 0,694 & 0,2126 & 0,000 & Valid \\
$\mathrm{X} 2.4$ & 0,851 & 0,2126 & 0,000 & Valid \\
\hline
\end{tabular}

Sumber : data diolah, 2020

Tabel 9. di atas mampu disimpulkan bahwa semua instrumen dalam variabel Empowerment (X2) adalah valid, hal ini dibuktikan dengan nilai masing-masing koefisien korelasi dari masing-masing item $r$ hitung > $\mathrm{r}$ tabel atau probablitas kurang dari 0,05, sehingga mampu digunakan dalam pengujian selanjutnya.

Tabel 10. Uji Validitas X.2

\begin{tabular}{|c|c|c|c|c|}
\hline Item & $\begin{array}{c}\text { Validitas } \\
\text { ( } \text { hitung) }\end{array}$ & $\mathrm{r}$ table & Prob. & Keterangan \\
\hline Y_1 & 0,763 & 0,2126 & 0,000 & Valid \\
Y_2 & 0,802 & 0,2126 & 0,000 & Valid \\
Y_3 & 0,585 & 0,2126 & 0,000 & Valid \\
Y_4 & 0,647 & 0,2126 & 0,000 & Valid \\
\hline
\end{tabular}

Sumber : data diolah, 2020

Tabel 10. Tabel di atas mampu disimpulkan bahwa semua instrumen dalam variabel efektivitas organiasi (Y) adalah valid, dibuktikan dengan nilai tiap koefisien korelasi dari setiap item $r$ hitung $>\mathrm{r}$ tabel atau probablitas kurang dari 0,05, sehingga mampu digunakan dalam pengujian selanjutnya.

\section{Uji Reliabilitas}

Uji reliabilitas merupakan indeks yang menunjukkan sejauhmana alat ukur mampu dipercaya atau diandalkan. Hasil yang diperoleh dari alat analisis SPSS kepada uji reliabilitas dengan teknik belah dua diperoleh hasil sebagai berikut :

\section{Tabel 11. Uji Reliabilitas}

\begin{tabular}{|l|c|c|}
\hline \multicolumn{1}{|c|}{ Variabel } & Nilai Alpha & Keterangan \\
\hline Recognition (recognition) $\left(\mathrm{X}_{1}\right)$ & 0,719 & Reliabel \\
\hline $\begin{array}{l}\text { Empowerment (Empowerment) } \\
\left(\mathrm{X}_{2}\right)\end{array}$ & 0,761 & Reliabel \\
\hline Efektivitas Organiasi $(\mathrm{Y})$ & 0,654 & Reliabel \\
\hline
\end{tabular}

Sumber: data diolah, 2020

Setiap variabel diperoleh koefisien alpha lebih besar dari 0,6. Bagi instrumen yang berupa alat tes atau angket, apabila koefisien alpha di atas 0,6, maka mampu disimpulkan bahwa alat ukur tersebut dikatakan reliabel. (Burhan Nurgiyantoro, 2000). Dengan demikian, data dari populasi yang penulis teliti termasuk dalam kategori valid dan reliabel, sehingga layak untuk dilakukan pengujian selanjutnya.

\section{Regresi Linier Berganda}

Mengetahui besarnya pengaruh motivasi, melalui recognition, empowerment terhadap efektivitas organisasi dilakukan dengan menggunakan metode statistik yaitu Regresi Linier Berganda. Mempermudah perhitungan analisis regresi linier berganda, maka berikut ini akan disajikan hasil olahan data dengan menggunakan program SPSS versi 16.00

Tabel 12. Hasil Regresi Linier

\begin{tabular}{|c|c|c|c|c|c|c|}
\hline Variabel & $\begin{array}{c}\text { Unstandardized } \\
\text { Coefficients }\end{array}$ & $\begin{array}{c}\text { Beta } \\
\text { (Standardized } \\
\text { Coefficients) }\end{array}$ & $t$ hitung & $t_{\text {tabel }}$ & Sig & Keterangan \\
\hline $\begin{array}{l}\text { Recognition } \\
\text { (recognition), }\end{array}$ & 0.307 & 0.447 & 4.189 & 1.6909 & 0.000 & Signifikan \\
\hline $\begin{array}{c}\text { Empowerment } \\
\text { (empowerment) }\end{array}$ & 0.463 & 0.638 & 5.973 & 1.6909 & 0.000 & Signifikan \\
\hline Konstanta & 0.909 & & & & & \\
\hline \multicolumn{7}{|c|}{$\begin{array}{ll}\mathrm{F}_{\text {hitumg }} & : 26.883\end{array}$} \\
\hline \multicolumn{7}{|c|}{$\mathrm{R} \quad: 0,783$} \\
\hline \multicolumn{7}{|c|}{ R square $\quad: 0,613$} \\
\hline \multicolumn{7}{|c|}{ Adjusted R Square $: 0,590$} \\
\hline
\end{tabular}

Sumber : data diolah, 2020

Tabel 12. menunjukkan hasil perhitungan reg- 
resi linier berganda, mampu disusun persamaan recognition, empowerment terhadap efektivitas organisasi mampu dijelaskan sebagai berikut :

$\mathrm{Y}=\mathrm{a}+\mathrm{b} 1 \mathrm{X} 1+\mathrm{b} 2 \mathrm{X} 2+\mathrm{e}$

$\mathrm{Y}=0,909+0,307 \mathrm{X} 1+0,463 \mathrm{X} 2$

Persamaan tersebut dijelaskan berikut ini:

1. Konstanta (a)

Nilai $\mathrm{a}=0,909$ menunjukkan besarnya variabel terikat efektivitas organiasi $(\mathrm{Y})$ yang tidak dipengaruhi oleh variabel variabel bebas recognition, empowerment sama dengan nol, maka efektivitas organiasi menujukkan nilai 0,909 dengan asumsi bahwa variabel bebas dalam keadaan konstan.

2. Koefisien regresi recognition $(\beta 1)$ Nilai $\beta 1=0,307$ menunjukkan adanya kenaikan variabel recognition yang mampu mengakibatkan kenaikan efektivitas organisai atau dengan kata lain setiap kenaikan recognition sebesar satu satuan akan menumbuhkan efektivitas organiasi sebesar 0,307 satuan, dengan asumsi variabel empowerment dalam keadaan konstan.

3. Koefisien regresi empowerment ( $\beta 2)$ Nilai $\beta 2=0,463$ menunjukkan adanya kenaikan variabel empowerment yang mampu mengakibatkan kenaikan efektivitas organisai atau dengan kata lain setiap kenaikan empowerment sebesar satu satuan akan menumbuhkan efektivitas organiasi sebesar 0,463 satuan, dengan asumsi variabel recognition dalam keadaan konstan.

Berdasarkan hasil pengujian regersi linier berganda menunjukkan bahwa dari kedua variabel recognition, empowerment mempunyai pengaruh yang positif dan searah dengan efektivitas organiasi.

\section{PengujianHipotesis}

\section{Uji Parsial (uji t)}

Digunakan untuk mengetahui apakah variabel bebas secara parsial mempunyai pengaruh yang signifikan terhadap variabel terikat Tingkat signifikansi adalah $\alpha=5 \%=0,025$

$$
\begin{aligned}
\mathrm{t}_{\text {tabel }(\alpha ; \mathrm{n}-\mathrm{k}-1)} & =0,05 ; \mathrm{n}-\mathrm{k}-1 \\
& =0,05 ; 37-2-1 \\
& =0,05 ; 34 .
\end{aligned}
$$

Nilai t tabel sebesar 1,6909.

Tabel 13. mampu dilihat bahwa nilai T-hitung untuk faktor recognition terhadap efektivitas organiasi adalah sebesar 4.189, sedangkan T-tabel kepada taraf nyata $(\alpha)$ yang digunakan sebesar $=5 \%$ dengan derajat kebebasan : $\mathrm{df}=(37-2-1=34)$ sehingga diperoleh nilai ttabel sebesar 1,6909. Hasil uji-t adalah sebagai berikut

Tabel 13. Hasil Uji t

\begin{tabular}{|l|c|c|c|}
\hline \multicolumn{1}{|c|}{ Variabel } & t-hitung & t-tabel & Keterangan \\
\hline Recognition (recognition) & 4.189 & 1,6909 & Signifikan \\
Empowerment (empowerment) & 5.973 & 1,6909 & Signifikan \\
\hline
\end{tabular}

Sumber : data diolah, 2020

Berdasarkan nilai t.hitung > t.tabel $(4.189>1,6909)$ serta nilai Signifikansi $<(\alpha)$ $(0,000<0,05)$, sehingga Ho ditolak dan $\mathrm{Ha}$ diterima. Artinya adalah secara parsial variabel recognition berpengaruh secara signifikan terhadap efektivitas organiasi Pada karyawan medical representative. Nilai t.hitung untuk faktor Empowerment terhadap efektivitas organiasi adalah sebesar 5.973 sedangkan ttabel kepada taraf nyata $(\alpha)$ yang digunakan sebesar $=5 \%$ dengan derajat kebebasan: $\quad$ df $=(37-2-1=34)$, sehingga diperoleh nilai ttabel sebesar 1,6909. Disimpulkan bahwa t.hitung > t.tabel $(5.973>1,6909)$ dan nilai signifikansi $<(\alpha)$ $(0,000<0,05)$,sehingga Ho ditolak dan $\mathrm{Ha}$ diterima. Artinya secara parsial variabel empowerment berpengaruh secara signifikan terhadap efektivitas organiasi kepada karyawan medical representative.

\section{Uji Simultan (Uji F)}

Digunakan untuk mengetahui apakah variabel bebas secara bersama-sama mempunyai pengaruh yang signifikan terhadap variabel terikat. Berdasarkan hasil perhitungan dengan menggunakan program SPSS diperoleh hasil sebagai berikut :

Tabel 14. Hasil Uji F

\begin{tabular}{|l|r|r|r|r|c|}
\hline Model & $\begin{array}{r}\text { Sum of } \\
\text { Square }\end{array}$ & \multicolumn{1}{c|}{ Df } & $\begin{array}{c}\text { Mean } \\
\text { Square }\end{array}$ & F & \multicolumn{1}{c|}{ Sig. } \\
\hline 1 Regresion & 3.901 & 2 & 1.951 & 26.883 & .000 \\
& 2.467 & 34 & 0.073 & & \\
$\quad$ Residual & 6.368 & 36 & & & \\
\hline \multicolumn{2}{|l|}{ Total } & &
\end{tabular}

Sumber: data diolah, 2020

Hasil perhitungan diperoleh F-hitung sebesar 26.883 yang berarti Fhitung (26.883) > F tabel $(3,2759)$ jadi Ho ditolak dan $\mathrm{Hi}$ diterima. 
Dapat disimpulkan bahwa secara simultan variabel bebas recognition, empowerment berpengaruh secara nyata terhadap efektivitas organiasi kepada karyawan medical representative, sehingga hipotesa yang menyatakan bahwa Faktor motivasi yang terdiri dari recognition dan empowerment secara parsial maupun bersama-sama berpengaruh signifikan terhadap effektivitas organisasi karyawan medical representative terbukti kebenarannya. Selanjutnya dengan menggunakan koefesien determinasi parsial ini $\left(\mathrm{r}^{2}\right)$. Berdasarkan hasil perhitungan SPSS diperoleh hasil koefisien determinasi parsial sebagai berikut :

1. Recognition $\left(\mathrm{X}_{1}\right)$ memiliki korelasi parsial sebesar 0,583 sehingga determinasi parsial $\left(\mathrm{r}^{2}\right)=0,3398$ atau sebesar 33,98\%

2. Empowerment $\left(\mathrm{X}_{2}\right)$ memiliki korelasi parsial sebesar 0,638 sehingga determinasi parsial $\left(\mathrm{r}^{2}\right)=0,5126$ atau sebesar $51.26 \%$
Berdasarkan hasil perhitungan $\mathrm{r}^{2}$ tersebut, maka mampu ditunjukkan bahwa variabel empowermentmemiliki pengaruh yang dominan terhadap effektivitas organisasi karyawan medical representativekarena koefisien determinasi parsial $\mathrm{r}^{2}$ variabel empowerment sebesar $51.26 \%$ lebih besar daripada variabel bebas lainnya. Dengan demikian hipotesa kedua tersebut mampu diterima dan terbukti kebenarannya.

\section{Uji Asumsi Klasik}

Beberapa uji asumsi klasik yang harus dipenuhi adalah normalitas multikolinieritas, heteroskedastisitas dan autokorasi:

\section{Normalitas}

Dalam mengetahui apakah data terdistribusi normal mampu digunakan probability plot. Model regresi yang baik adalah adanya pendistribusian data normal atau mendekati normal yang mampu dilihat kepada gambar berikut ini :

\section{Normal P.P Plot of Regression Standardized Residual}

Dependent Variable: Efektivitas Organisasi

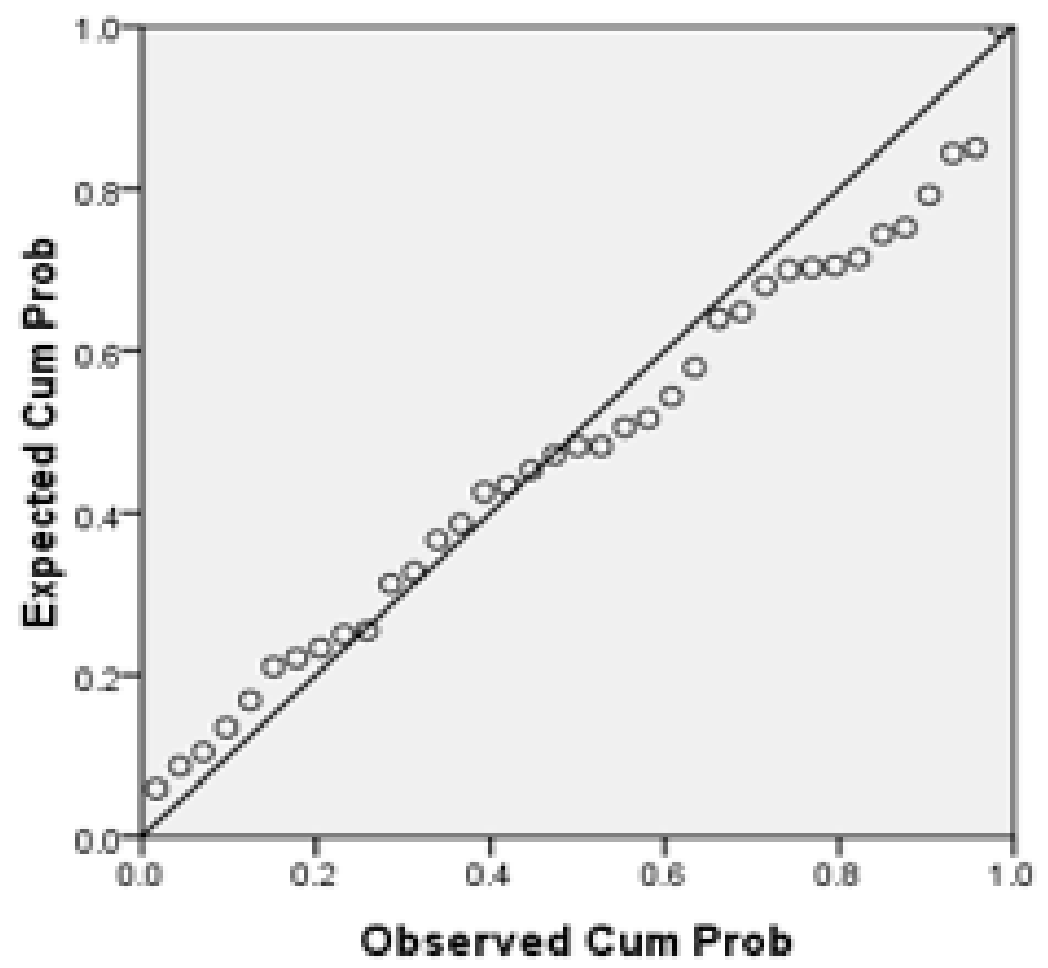

Gambar 2. Plot Probability 
Berdasarkan Gambar 2. menunjukkan bahwa penyebaran titik-titk mengikuti garis regresi, sehingga data terdistribusi normal
Pengujian ini digunakan untuk mengetahui apakah variabel pengganggu dalam persamaan regresi mempunyai varians yang sama atau tidak.

\section{Partial Regression Plot}

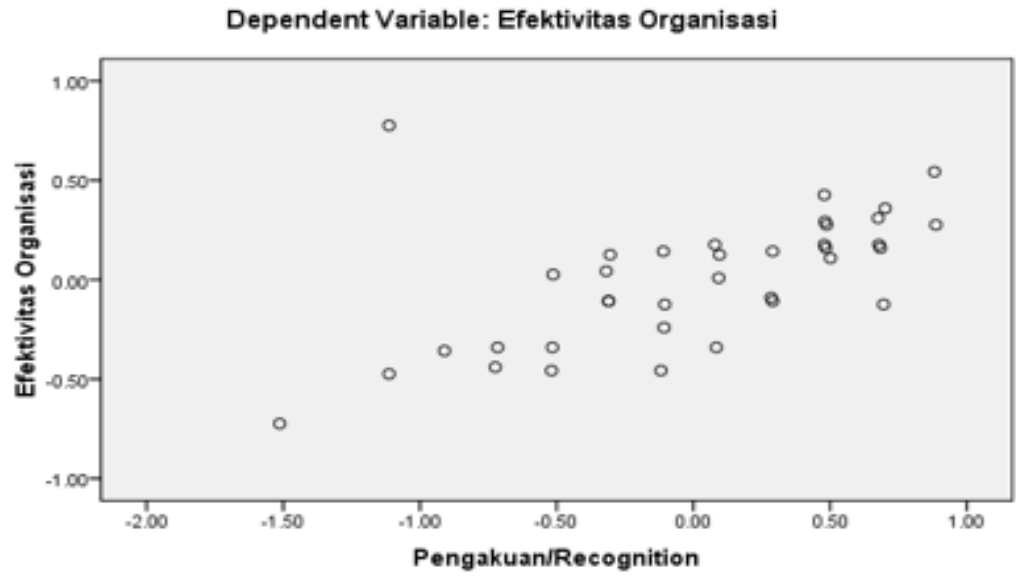

Partial Regression Plot

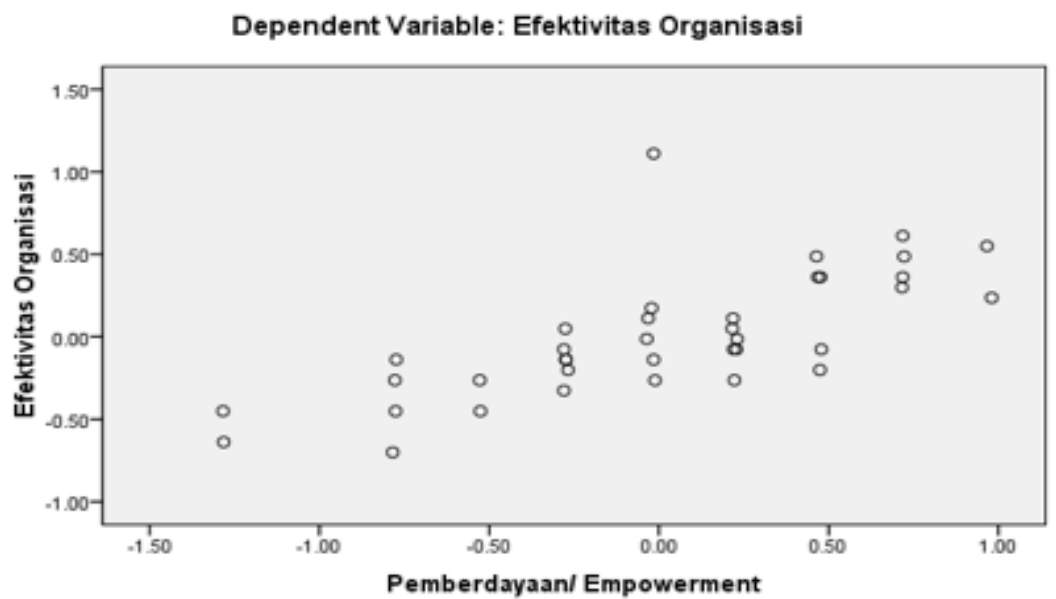

Gambar 3. Heteroskedasitas

\section{Multikolinieritas}

Uji Multikolinieritas kepada penelitian ini digunakan untuk mendeteksi adanya gejala Multikolinieritas dalam pengujian keeratan hubungan antar variabel bebas, tercermin dari Coefficient. Hal ini tampak kepada nilai tolerance danVariance Inflation Factor (VIF)untuk setiap variabel bebas. Jila nilai tolerance lebih dari 0,10 dan nilai kurang dari 10, artinya menunjukan tidak termampu korelasi antar satu variabel bebas. Berdasarkan hasil perhitungan menunjukan bahwa nilai
Variance Inflation factor (VIF) dari semua variabel bebas, meliputi :

Tabel 15. Nilai VIF (Variance Inflation Factor)

\begin{tabular}{|l|c|c|}
\hline \multicolumn{1}{|c|}{ Variabel Bebas } & Tolerance & VIF \\
\hline Recognition & 1.000 & 1.000 \\
\hline Empowerment & 1.000 & 1.000 \\
\hline
\end{tabular}

Sumber : data diolah, 2020

recognition, empowerment memperlihatkan nilai yang kurang dari sepuluh, berarti 
persoalan multikolinieritas antara semua variabel bebas mampu ditolerir atau tidak termampu adanya gejala Multikolinieritas.

\section{Autokorelasi}

Mengetahui ada tidaknya gejala autokorelasi dalam model penelitian dengan melihat nilai DW tabel. Diketahui jumlah variabel bebas adalah $2(\mathrm{k}=2)$ dan banyaknya data adalah (n $=37$ ) sehingga diperoleh nilai DW sebesar 1.961 tabel adalah sebesar $\mathrm{d}_{\mathrm{L}}=1.364$ dan $\mathrm{d}_{\mathrm{U}}=$ 1.590. Untuk mendeteksi ada atau tidaknya autokorelasi ini digunakan uji Durbin Watson (DW) dengan ketentuan sebagai berikut (Makridakis dalam Sulaiman, 2004; 16 )

\begin{tabular}{|c|c|c|c|}
\hline Variabel & $\begin{array}{c}\text { Nilai } \\
\text { DW } \\
\text { Test }\end{array}$ & Ketentuan Daerah & Keterangan \\
\hline $\begin{array}{l}\text { Efektivitas } \\
\text { Organiasi }\end{array}$ & 1.961 & $\begin{array}{l}0-1,592 \text { (ada auto } \\
\text { korelasi) } \\
1,592-2.4087 \\
\text { (daerah ketidak } \\
\text { pastian) } \\
1,592-1.578 \text { (tidak } \\
\text { ada autokorelasi) } \\
1,578-2.242 \\
\text { (daerah ketidak } \\
\text { pastian) } \\
2.242-4 \text { ( ada } \\
\text { autokorelasi) }\end{array}$ & $\begin{array}{c}\text { Tidak ada } \\
\text { autokorelasi }\end{array}$ \\
\hline
\end{tabular}

Sumber : data diolah, 2020

Hasil perhitungan DW dan hasil tabel durbin watson dimampukan nilai dL: $1578<1.961$ $<$ du 2.242, sehingga mampu disimpulkan berada daerah ketidakpastian korelasi

\section{PEMBAHASAN}

\section{Recognition terhadap Efektivitas Organiasi}

Berdasarkan hasil pengujian secara parsial dimampukan bahwa variabel recognition berpengaruh terhadap efektivitas organisasi hal ini mampu dilihat dari nilai signifikansi $<0.05$. Sesuai dengan hasil penelitian Bennett dan O'Brien (dalam Griego, 2000) mengemukakan dengan kuat bahwa balasan atau recognition dan penghargaan merupakan aspek penting dalam membangun sebuah organisasi pembelajaran. Lebih jauh dikemukakan bahwa sistem pemberian hak dan penghargaan harus mendukung dan mendorong pembelajaran karyawan dan organisasi. Bentuk dari hal ini bisa bermacam-macam, misalnya memberi penghargaan bagi karyawan yang berani mengambil risiko untuk menawarkan ke organisasi rencana pembagian-keuntungan yang berguna bagi setiap orang ketika organisasi tumbuh belajar dan bertumbuh.

Berdasarkan keadaan penelitian menunjukkan bahwa, recognition selama ini yang rasakan oleh karyawan kepada karyawan medical representative cukup kurang, hal ini mampu dilihat bagi karyawan yang prestasi belum mampudiberikan perhatian khusus seperti pemberian hadiah atau bonus sehingga kurang perhatian dari organisasi. Selama ini karyawan hanya diberi gaji sesuai dengan target kerja dari organisasi. Untuk menumbuhkan motivasi dilihat dari faktor recognition sebaiknya organisasi khususnya di karyawan medical representative memberikan perhatian berupa penghargaan kenaikan jabatan atau penambahan uang insentif bagi karyawan kekepada yang memiliki kinerja baik.

\section{Empowerment terhadap Efektivitas Organisasi}

Berdasarkan hasil pengujian empowerment berpengaruh terhadap efektivitas organisasi hal ini mampu dilihat dari nilai signifikansi $<0.05$. Hasil uji mendukung penelitian Sadarusman (2004) Empowerment dan berarti saling berbagi informasi dan pengetahuan diantara karyawan yang digunakan untuk memahami dan mendukung kinerja organisasi, pemberian penghargaan terhadap kinerja organisasi dan pemberian otonomi dalam pengambilan keputusan yang berpengaruh terhadap organisasi.

Menurut hasil penelitian menunjukkan selama ini empowermentkepada karyawan medical representative cukup, selama ini karyawan diberikan suatu kebebasan dalam melakukan semua pekerjaan serta berbagi pengetahuan, keterampilan dan mempunyai rasa percaya diri yang tinggi dalam menjalankan tugasnya, ehingga agar efektivitas organiasi berjalan lancar pihak manager untuk selalu memberikan otoritasi kepadakaryawan dalam pekerjaannya. Pimpinan di berbagai tingkatan selalu mengkomunikasikan dan juga mensosialisasikan berbagai kebijakan organisasi pada karyawan sehingga karyawan menmampukan perhatian dari atasan. Selain itu, juga selalu menjaga hubungan baik dengan bawahan efektivitas organisasi mampu berjalan lancar dan saling membentuk suatu kekeluargaan. 


\section{KESIMPULAN}

Hasil pengujian hipotesa pertama menunjukkan bahwa Faktor motivasi yang terdiri dari recognition dan empowerment secara parsial maupun bersama-sama berpengaruh signifikan terhadap effektivitas organisasi karyawan medical representative terbukti kebenarannya. variabel empowerment memiliki pengaruh yang dominan terhadap effektivitas organisasi karyawan medical representative dari pada variabel bebas lainnya.

\section{Saran}

Berdasarkan hasil penelitian ini, maka mampu diajukan beberapa saran yang diharapkan mampu menjadi bahan pertimbangan bagi pihak yang berkepentingan kepada organisasi :

1. Organisasi memperhatikan kompensasi yang diberikan, kepada karyawan yang memiliki prestasi dan kinerja pada departemen maupun karyawan medical representative, sehingga mampu menumbuhkan efektivitas organisasi.

2. Perusahaan menumbuhkan semangat kerja karyawan, dengan cara memperbaiki dan memfasilitasi kebutuhan yang diinginkan karyawan, seperti insentif dan sarana transportasi dan komunikasi, serta fasilitas bekerja lainnya. Selain itu, perlu membaiki nilai - nilai budaya agar keberhasilan pelaksanaan program budaya kerja antara lain mampu dilihat dari peningkatan tanggung jawab, peningkatan kedisiplinan dan kepatuhan kepada norma/ aturan, terjalinnya komunikasi dan hubungan yang harmonis dengan semua tingkatan, peningkatan partisipasi dan kepedulian, peningkatan kesempatan untuk pemecahan masalah dan berkurangnya tingkat kemangkiran dan keluhan.

\section{DAFTAR PUSTAKA}

Andriani, M. \& Widiawati, K., 2017. Penerapan Motivasi Karyawan MenurutTeori Dua Faktor Fredrrick Herzberg Pada Pt Aristika Kreasi Mandiri. JurnalAdministrasi Kantor, Vol 5(No 1), Pp. 83-98.

Arikunto, S. 2002. Metodologi Penelitian Suatu Pendekatan Proposal. Jakarta: PT. Rineka Cipta

Budi, 2007. Data Mining Teknik Pemanfaatan Data untuk Keperluan. Bisnis. Yogyakarta : Graha Ilmu
Ghozali, Imam. 2005. Aplikasi Analisis Multivariate dengan SPSS. Semarang: Badan Penerbit UNDIP

Herzberg, Frederick. 2008. Herzberg"s Motivation-Hygiene Theory and Job Satisfaction in The Malaysian Retail Sector: The Mediating Effect Of Love Money. Sunway UniversityMalaysia: Teck Hang Tan and Amna Waheed

Manoor, Q. A. 2020 "1

Manoor, Q.A. 2012. Impact of Employees Motivation on Organizational. Effectiveness. European Journal of Business and Management, 3 (3), 36-44

Riduwan. (2007). Rumusdan Data dalam Aplikasi Statistika. Bandung: Alfabeta

Robbins, Stephen P. 2001. Perilaku Organisasi: Konsep, Kontroversi, Aplikasi, Jilid. 1, Edisi 8, Prenhallindo, Jakarta.

Singarimbun, Masri dan Shofian Effendi. 1995. Metode Penelitian Survey. Jakarta: LP3ES

Steers. 1991. Perilaku Organisasi. Jakarta :Erlangga. 1997. Efektivitas Organisasi

Sugiyono. 2004. Metode Penelitian. Bandung: Alfabeta

Sujarweni, 2007, "Panduan Mudah Menggunakan SPSS \& Contoh. Penelitian Bidang Ekonomi ", Penerbit Ardana Media, Cetakan Pertama. Februari 2007.

Umar. (2003). Metode Riset Perilaku Konsumen Jasa. Jakarta : Ghalia. Indonesia

Widayat (2004). "Metode Penelitian Pemasaran (Aplikasi SoftwareSPSS)". Malang : UMM

Zainun.2001, Manajemen Sumber Daya Manusia Indonesia, PenerbitGunung Agung, Jakarta. 